\title{
Testing the Prediction of Knowledge Sharing Behavior through the Lens of Organizational Culture and Organizational Citizenship Behavior
}

\author{
Siddig Balal Ibrahim1, Umair Ahmed ${ }^{1, *}$ and Mohammed Sani Abdullahi \\ ${ }^{1}$ Arab Open University, Bahrain \\ siddiq.ibrahim@aou.org.bh; umairahm@gmail.com \\ ${ }^{2}$ Yusuf Maitama Sule University Kano, Nigeria. \\ abdulmohdsani@gmail.com \\ *Correspondence: umairahm@gmail.com
}

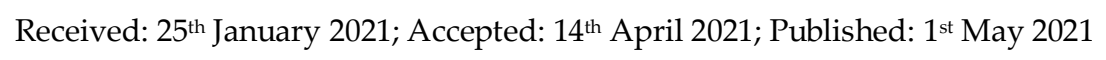

Abstract: This research intended to focus on the impact of organizational culture on knowledge sharing by bank employees directly and indirectly through mediation by organizational citizenship behavior. For achieving the purpose, 402 employees from banks in the Kingdom of Bahrain through simple random sampling. Data were collected through questionnaires. A current study found a significant outcome of organizational culture on knowledge sharing and organizational citizenship behavior. Besides this current study also found significant results between organizational citizenship behavior and knowledge sharing. Along with significant direct results, current research also found the mediating effect by organizational citizenship behavior in relationships of organizational culture with knowledge sharing. The current study contributes notable theoretical implications under social exchange theory. In addition, the current study also provides practical learnings and recommendations for the future.

Keywords: Organizational culture; Organizational Citizenship Behavior; Knowledge Sharing; Banking Sector

\section{Introduction}

Knowledge development is a key motivator for the global economic world (Eder \& Trippl, 2019). In the modern era, the global economy is transforming towards a knowledge-based economy (AlZgool et al., 2020). Additionally, it is observed by Bloodgood (2019) that knowledge has a distinct competitive edge to survive in the competitive world with distinct competency, which competitors cannot easily imitate. Mahdi, Nassar, and Almsafir, (2019) found that knowledge management has a significant contribution in the public and private organizations to maintain sustainable competitive performance. In emerging economies, a skilled and knowledgeable workforce is the central pillar of sustainable organizational performance. From the economic perspective, it is not easy to transform all the factors of production from tangible to intangible (LaFayette, Curtis, Bedford, \& Iyer, 2019). This transformation of the resources urges to management scholars to explore more and more about the field of knowledge management. Therefore, 
the knowledge management concept has been varied according to the existing culture of the country. According to Brown and Pehrson (2019); Hofstede and Hofstede (2005), several scholars have explored that culture is the product of social contact among groups and peers.

Haag, Duan, and Mathews (2010) discussed that socialization contributes to upgrading cultural values with dynamic environmental change. Additionally, it adds value creation in the exchange of creative ideas, knowledge and perceptions. Hence, there are many consequences of the propensity to perceive culture as a social system. For instance, knowledge-based culture influences behavior, thinking process, rules, procedures, ideas, and administration and control. Consequently, culture tends to change over time with the alignment of the radical change at the global level (Huang \& Wang, 2003). Cultural differences can influence perceptions and dissemination of information despite growing globalization.

Nevertheless, the use of tacit awareness involves social contact. The continuous process of sharing life and work-related proficiencies through social contact with others and replicating them with learning can be a basis for producing, sharing, and transmitting information (Hadjimichael \& Tsoukas, 2019). It is also observed that social communication can take place, especially those aggregated cultures where different ethnic groups and racial backgrounds share their emotions, feelings, perceptions, and ideas. In any organization, the culture transforms a systematic way forward to learn, adapt and create a strong environment where every person has the right to share valuable insights, which create value addition in the organizational culture for the people. For instance, Organizational culture, which is essential for the formation and sharing of information, seeks to control individual actions. Therefore, organizations can also create an atmosphere in which individuals can use their cognitive skills to create knowledge and share creative ideas in the workplace.

Memon, Syed, and Arain (2017) delineated that flexibility in knowledge-based culture has a significant role in creating knowledge, ideas, and meaningful thoughts. Moreover, community encourages and promotes collaboration and teamwork between individuals to promote information streams and to promote innovative ways to solve the problems. In the current era, financial institutions in general and the banking sector have been considered a fundamental driver of innovation, smart technology, and change. Thus, this is important for organizations to implement a knowledge-based system that can ensure people sustain in the competitive environment with prompt speed of change in recent times (Sachdeva, 2019). It is also explored that many industries and firms in the financial sector have adopted the robotics system to enable knowledge creation, sharing, and creative ideas to their stakeholders.

According to Stamper and Dyne (2001), organizational citizenship behavior has a significant role in the organizational culture that directly or indirectly influences employee behaviors. It is found that citizenship behaviors within the organization improve staff and organizational efficiency (Podsakoff, Whiting, Podsakoff, \& Blume 2009). As per research by Ahmed, Arshad, Mahmood, and Akhtar (2019), the growing significance has led scholars to consider helping behavior as the main components of sharing information being a vital indicator of ethical behavior. Although previous research covered different facets of information management in the banking sector, there is still a need to identify organizational culture as a predecessor to the conception and transfer of knowledge.

This study aims to examine the culture as a prime antecedent that may pertain to knowledge creation, sharing, and transfer and how organizational citizenship behavior mediates the association between organizational culture and knowledge sharing behavior.

\section{Literature Review}

\subsection{Banking Sector of Bahrain}

In Bahrain, the banking sector consisted of two main streams, including Islamic and conventional banking systems that constitute up to $85 \%$ of the total financial assets of Bahrain. It is also observed that 29 banks are providing retail financial services through a conventional banking system while 73 banks have 
wholesale services with overseas representative branches of 8 other banks. Moreover, it is confirmed by Banks in Bahrain (2019) that the banking sector has a significant role in booming the financial sector. Besides, this is considered a big achievement that banking sector assets have reached 192.7 billion dollars in 2016, which is more than the GDP of Bahrain. In connection to research, Bahrain banking sector has also attracted scholars investigating various factors (AlZgool, Ahmed, Pahi \& Ammar, 2020; Ahmed, 2019).

Bahrain has become a regional port for financial institutions with a robust regulatory structure and skilled staff, attracting international banks to offer their services in the country. However, as a small economy with just 1.5 million population, the banks themselves have the opportunity and the likelihood of tough competition due to international openings of banks (Oxford, 2019). In a way, this leads to emphasizing the need for banks to demonstrate how they can work actively to boost or improve their financial results to ensure competitive viability. Fortunately, this is not simply confined with the competitive financial goods or services they can provide, but they can also focus on the work practices and procedures that are practically proved to enhance the organization's financial performance (Chun Shim, Choi, \& Kim, 2013).

\subsection{Knowledge Sharing}

Knowledge sharing has emerged through the knowledge management concept, defined by Alavi and Leidner (2001) as a source of identifying and using collective knowledge within organizations to control business rivals. In such a situation key part of managing knowledge is sharing and accessing knowledge in or outside of particular organizations. Literature related to knowledge management defines knowledge sharing as a way of transmitting information and utilizing expertise for solving the key problems by developing new ways and implementing the required rules as stated by Chan, Wang, and Wang (2018); Cummings (2004). While different scholars define knowledge sharing as a process of promoting, initiation, integrating and implementing multi-stage process (Yu, \& Wang 2018), transferring or searching (Tamer Cavusgil, Calantone, \& Zhao 2003), or sharing and assimilation (Wang 2019; Tamayo-Torres, Roehrich, \& Lewis 2017).

Unfortunately, knowledge sharing has remained a neglected area by human resource professionals for many years. In early 2000, the importance of knowledge management has been started. Blankenship and Ruona (2009) also highlighted that after 2000, knowledge management has remained under focus in the field of human resources. This highlights that it is not essential only to accumulate knowledge but also

to share gathered knowledge. Based on stated earlier, this research has defined knowledge sharing, collecting and delivering the knowledge to different concerned personnel.

\subsection{Organizational Culture}

Process of beliefs, habits, values, and behavior that shape individuals' behavior within an organization is known as organizational culture. According to Eskiler, Ekici, Soyer, and Sari (2016), organizational culture is a combination of beliefs and values inside the organization that direct employee behavior. Eskiler et al. (2016) further added that this makes organizational culture give birth to innovative work behavior that enables the leaders to be motivated to have competitive advantage. Additionally, Khan, Memon, and Ramayah (2018) have resembled organizational culture like glue, which combines or attaches employees and the organization system to generate positive and innovative work behavior.

\subsection{Organizational Culture and Knowledge Sharing}

Organizational culture has remained under great focus since decades because of having potential growth and better organizational performance, as stated by Bendak, Shikhli, and Abdel-Razek (2020); Villalobos Antúnez, and Ganga Contreras (2018). Different organizational cultures have varying effects on results. Again the organizational culture structure the employee behavior as the output of values and a 
combination of behavior, attitude, and intention. Abbasi and Dastgeer (2018) narrated that organizational culture is a great forecasting factor of knowledge sharing.

Social exchange theory explains the social norms and values in directing the behavior of individuals. Aquilani, Abbate, and Codini (2017) are among recent studies that have established that organizational culture is positively associate with knowledge sharing. People keenly disseminate knowledge in an environment of mutual trust and confidence, whereas in a competitive environment where people might be jealous and competing may hoard their knowledge to gain and retain knowledge power. An advantage of clan culture is that it enables the free flow of knowledge, develops confidence and trust among organizational members, connects and affiliates people, and refrains from anti-social norms. These features of clan culture encourage people at the workplace and in any other social setup to willingly share knowledge and experience and understanding their knowledge-sharing behavior (Asurakkody \& Kim, 2020).

Knowledge sharing is a key component of knowledge management. Based on the social exchange theory, knowledge sharing play a basic role in knowledge management. So, the organizational culture that acknowledges the values and norms of knowledge sharing would make sure harmless flow of information from donor to the receiver. Despite excessive research on examining the impact of organizational culture on knowledge sharing, there is a lack of empirical research on measuring the effect of organizational culture towards knowledge sharing and the mediating influence of organizational citizenship behavior. There is a dearth of research to examine knowledge sharing in the banking industry of the Kingdom of Bahrain. Thus the present study hypothesized:

H1: Organizational culture will significantly influence the knowledge sharing.

\subsection{Organizational Citizenship Behavior}

Organizational citizenship behavior is a combination of voluntary behavioral actions that are not traced out with rewards but help promote organizations (Organ 1988). Past literature has identified different factors influencing organizational citizenship behavior; these factors are organizational justice, perceived organizational support, and authentic leadership (Colquitt, Conlon, Wesson, Porter, \& Ng 2001; Riggle, Edmondson, \& Hansen 2009). Investigated by Lim and Loosemore (2017) that organizational citizenship behavior helps achieve organizational goals. According to Organ (1988), scholars have only focused on contextual, effectual, and cognitive factors. Furthermore, Bambale (2014) explained that the OCB defines behavior and activities required by leaders from employees to achieve objectives and goals. Su ch as helping and guiding new workforce, increasing workflow, doing work for extra time, corporation of different events and providing fruitful suggestions related to development. This research has been aimed to study organizational culture effects on organizational citizenship behavior in the banking industry of the Kingdom of Bahrain.

\subsection{Organizational Culture and Organizational Citizenship Behavior}

Organizational citizenship behavior has remained in focus since long different scholarly work has focused on the relationship of OCB and different occupations in various organizations as narrated by Ebrahimpour, Zahed, Khaleghkhah, and Sepehri (2011). Organizational culture affects different factors, including organizational citizenship behavior (Badawy, Trujillo, \& Magdy, 2017). Accordingly, the study conducted on the university staff found a weak impact of organizational culture on organizational citizenship behavior. Besides, studies such as Mohanty and Rath (2012); Ghashghaeinia and Hafezi (2015); Patra and Aima (2018) found a significant connection of organizational culture and organizational citizenship behavior. The prior literature also found significant positive influence of organizational culture on organizational citizenship behavior (Mahardika, \& Wibawa 2019; Demirel, Elhusadi, \& Alhasadi, 2018; Wijaya, \& Yuniawan, 2017; Setyaningrum 2015). Similar results have also been forwarded by some other 
scholars (Cahyono, Sularso, \& Sumani, 2016; Purnama, 2013). This hence clarifies that good organizational culture will positively increase the OCB of staff. Thus we hypothesized:

H2: Organizational culture significantly predict organizational citizenship behavior.

\subsection{Organizational Citizenship Behavior and Knowledge Sharing}

People with OCB have an open mind and willingness to share knowledge with their social circle (Hsu \& Lin, 2008). Knowledge sharing behavior has been influenced positively by OCB, and people with a higher level of OCB are more willing and volunteer for the welfare of others (Pei-Lee, \& Hongyi, 2012). This, in return, also increases the tendency of sharing knowledge. A scholarly work by Hsien, Pei Yung, and Sheng (2014) researched the catering industry and found positive influence of OCB on knowledge sharing behavior. Mogotsi, Boon, and Fletcher (2011) have shown resemblance in knowledge sharing and OCB based on discretionary behavior.

H3: Organizational citizenship behavior will significantly predict knowledge sharing.

\subsection{Organizational Citizenship Behavior as a Mediator}

Different scholars such as Hashim and Tan (2015); Jo and Joo (2011); Andrews and Delahaye (2000); Lin (2006) have examined mediators with knowledge sharing. These researchers have investigated the link of antecedents with knowledge sharing, such as organizational learning culture (OLC), organizational commitment (OC), and OCB. Furthermore, Jo and Joo (2011) found a significant link between OCB and knowledge sharing intention. The finding suggested that OCB has mediated the association between organizational learning culture and knowledge sharing intention. OCB has been proved as the mediator between POS and Job performance (Chiang, \& Hsieh, 2012) further narrated that staff with a higher level of OCB exceed expectations and do more than their job assignments. Similarly, OCB also mediated between servant leadership and knowledge sharing intention (Tuan, 2017). As stated in existing literature, OCB has performed as a mediator among different variables such as POS, knowledge sharing intention, and job performance, showing that OCB is a good mediator in organizational research. Though lack of literature about testing mediating effect of OCB in the relationship of organizational culture and knowledge sharing in the banking sector is yet to be explored. Therefore, this research has investigated the mediating relationship of OCB between organizational culture and knowledge sharing among bank employees of the Kingdom of Bahrain.

H4: Organizational citizenship behavior will significantly mediate the association of organizational culture towards knowledge sharing.

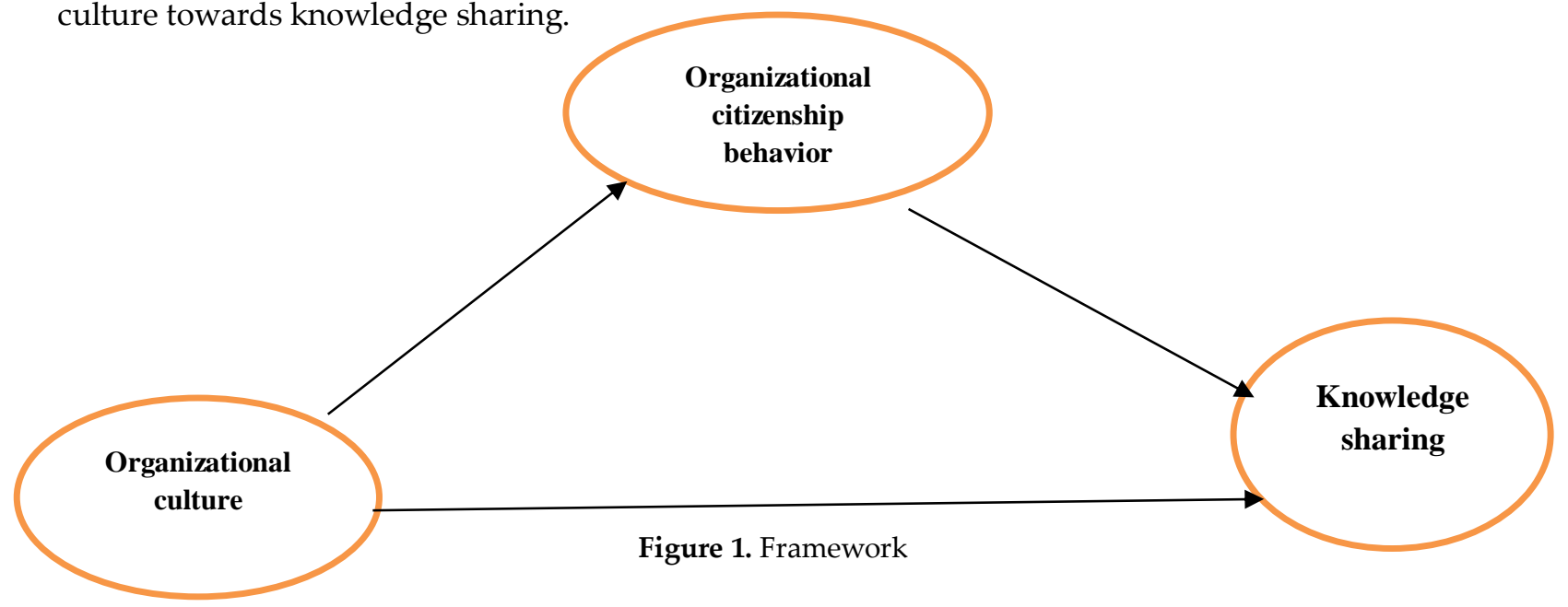




\section{Methodology}

\subsection{Instrumentation}

Questionnaire was structured in the following manner. Firstly, the questionnaire contained description about respondents ' profile. Secondly, information about organizational culture, organizational citizenship behavior, and knowledge sharing behavior of bank employees in the Kingdom of Bahrain. Instrument items were selected from the literature available. Organizational culture has been operationalized as a uni-dimensional variable as used as uni-dimensional in the study of Khan, Ismail, Hussain, and Alghazali (2020). Organizational culture was assessed with 6 items adapted from Cameron and Quinn (1999) recently been used in Fralinger and Olson (2007), and items are available in Cameron and Quinn (2006) revised edition. Besides this, organizational citizenship behavior was measured through 8 questions were adapted from Podsakoff et al. (1990), while knowledge sharing was measured through 5 items adapted from Bock et al. (2005) and recently been used in Chow and Chan (2008).

\subsection{Data Collection}

Data were collected from a sample of 402 (after data screening) individual bank staff working in different banks in the Kingdom of Bahrain. The sample was selected through simple random sampling. Data were collected using a self-administrative questionnaire. Human resource units and operational incharge personnel were contacted to arrange a proper list of working staff, then after respondents were approached for filling of questionnaires. The demographic profile of the respondents is presented in table 1.

Table 1. Demographic profile of respondents $(n=402)$

\begin{tabular}{|c|c|c|c|c|}
\hline Demographic factor & Component & & Frequency & Percentage \\
\hline \multicolumn{5}{|l|}{ Gender } \\
\hline & Male & & 330 & 82.09 \\
\hline & Female & & 18 & 17.91 \\
\hline \multicolumn{5}{|l|}{ Age } \\
\hline & $<=24$ years & & 43 & 10.70 \\
\hline & $25 \mathrm{Y}$ to $30 \mathrm{Y}$ & & 95 & 23.63 \\
\hline & $31 Y$ to $35 Y$ & & 119 & 29.60 \\
\hline & $36 \mathrm{Y}$ to $40 \mathrm{Y}$ & & 99 & 24.63 \\
\hline & More than 40 years & & 46 & 11.44 \\
\hline \multicolumn{5}{|l|}{ Qualification } \\
\hline & Graduate & & 310 & 77.11 \\
\hline & Postgraduate & & 92 & 22.89 \\
\hline \multicolumn{5}{|l|}{ Marital status } \\
\hline & Single & & 190 & 47.26 \\
\hline & Married & 127 & & 31.59 \\
\hline & Not specified & & 85 & 21.14 \\
\hline
\end{tabular}

$\mathrm{Y}=$ years

\subsection{Data Analysis}

By following the data analysis process from Ibrahim and Arshad (2017), hypothesized relationships were examined by applying structural equation modeling. This study applied two approaches as recommended by Anderson and Gerbing (1998). At first, the measurement model was assessed through the PLS algorithm using Smart PLS 3 software to check the reliability and validity of the model. Later, the study assessed the structural model for proposed relationships. Smart PLS 3 has been widely used across social science studies (e.g., Ahmed et al., 2020; Pahi et al., 2020). 


\section{Analysis Results}

\subsection{Assessment of Measurement Model}

In the measurement model, validity and reliability were checked by following Fornell and Larcker (1981) criteria in which construct validity was assessed via composite reliability coefficients to be 0.70 or above. Furthermore, convergent validity of the variables was assessed through AVE score by value of 0.50 and or above. 0.50 (Chin 1998). CR values were found among 0.869 to 0.944 , and AVE scores were 0.530 to 0.773. Thus current study assured internal consistency reliability. Furthermore detail is appended in table 2 and figure 2.

Table 2. Loadings, AVE, CR, and $\mathrm{R}^{2}$

\begin{tabular}{|c|c|c|c|c|c|c|c|}
\hline \multirow{2}{*}{\multicolumn{2}{|c|}{$\begin{array}{l}\text { Construct } \\
\text { Organizational Culture }\end{array}$}} & \multirow[t]{2}{*}{ AVE } & \multicolumn{2}{|r|}{ CR } & \multicolumn{2}{|c|}{$\mathbf{R} 2$} & \\
\hline & & & 0.530 & & 0.869 & & \\
\hline OC.1 & 0.552 & & & & & & \\
\hline OC. 2 & 0.614 & & & & & & \\
\hline OC.3 & 0.678 & & & & & & \\
\hline OC. 4 & 0.835 & & & & & & \\
\hline OC. 5 & 0.833 & & & & & & \\
\hline OC.6 & 0.805 & & & & & & \\
\hline \multicolumn{2}{|c|}{ Organizational Citizenship Behavior } & 0.657 & & 0.938 & & 0.583 & \\
\hline OCB1 & 0.739 & & & & & & \\
\hline OCB2 & 0.716 & & & & & & \\
\hline OCB3 & 0.637 & & & & & & \\
\hline OCB4 & 0.871 & & & & & & \\
\hline OCB5 & 0.864 & & & & & & \\
\hline OCB6 & 0.882 & & & & & & \\
\hline OCB7 & 0.875 & & & & & & \\
\hline OCB8 & 0.863 & & & & & & \\
\hline Knowledg & & & 0.773 & & 0.944 & & 0.469 \\
\hline KS.1 & 0.884 & & & & & & \\
\hline KS.2 & 0.909 & & & & & & \\
\hline KS.3 & 0.907 & & & & & & \\
\hline KS.4 & 0.855 & & & & & & \\
\hline KS.5 & 0.839 & & & & & & \\
\hline
\end{tabular}

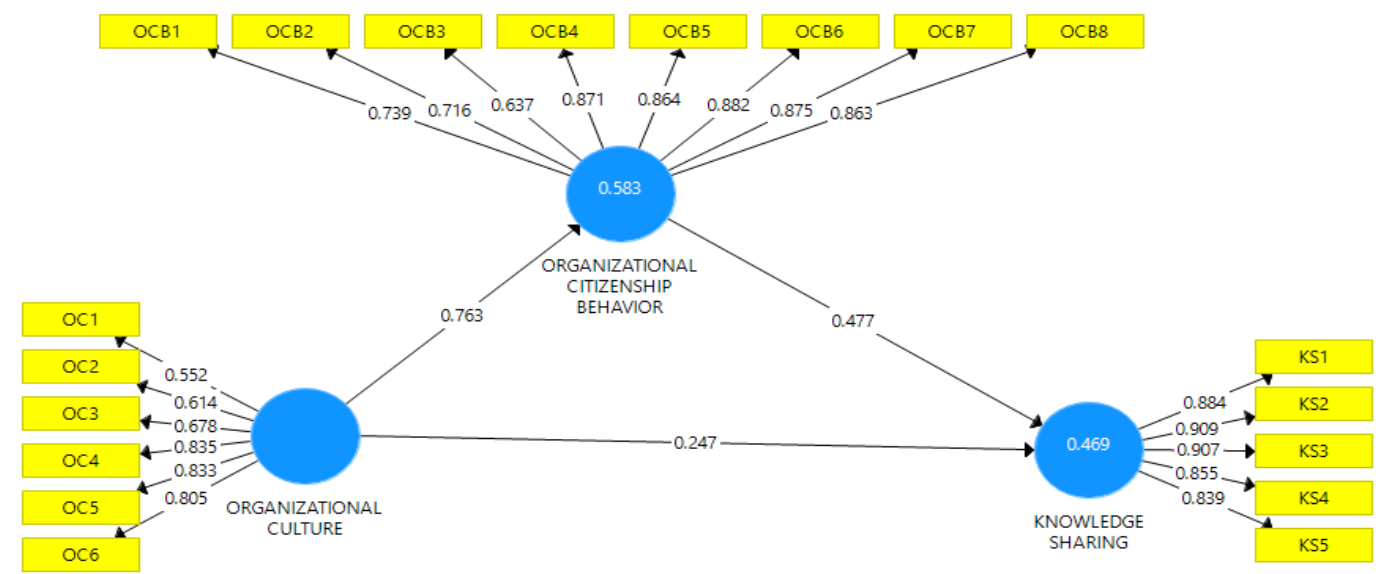

Figure 1. Measurement Model

Following this, the current study attempted to measure the discriminant validity of the model. Chin (1988) recommended that the square root of the AVE scores must be higher than compared reflective loading. Furthermore, for measuring the discriminant validity, HTMT values were also assessed by following Henseler, Ringle, and Sarstedt (2015)'s recommendations. Recommended values of HTMT lies below HTMT0.85 or HTMT0.90. Further square root of AVE and HTMT values are presented in table 3. 
Results in table 3 show that the square root of AVE (Fornell \& Larcker, 1981) of all latent variables are higher than the compared reflective loading. Furthermore all HTMT values were under the recommended range of HTMT0.90. Hence current study confirms significant discriminant validity.

Table 3. Discriminant Validity

\begin{tabular}{|c|c|c|c|c|c|c|}
\hline \multirow[t]{2}{*}{ Construct } & \multicolumn{3}{|l|}{ Sqr root AVE } & НTMT & \multirow[b]{2}{*}{ ОСВ } & \multirow[b]{2}{*}{ OC } \\
\hline & KS & OCB & OC & KS & & \\
\hline KS & $0.879 *$ & & & & & \\
\hline ОСВ & 0.666 & $0.811^{*}$ & & 0.698 & & \\
\hline $\mathrm{OC}$ & 0.611 & 0.763 & $0.728^{*}$ & 0.695 & 0.889 & \\
\hline
\end{tabular}

* Bold value represent square root of AVE

\subsection{Assessment of Structural Model}

After successful assessment of measurement model, the current study assessed structural model to check proposed hypothesis through bootstrapping. Bootstrapping is widely used in research for testing the hypothesized relationships (Galdeano, Ahmed, Fati, Rehan, \& Ahmed, 2019). In the assessment of structural model, the current study found significant relationship of organizational culture with knowledge sharing in $\mathrm{H} 1(\mathrm{OC} \rightarrow \mathrm{KS})(\beta=0.247, \mathrm{sd}=0.062, \mathrm{t}=4.003, \mathrm{p}<=0.000)$ hence H1 was accepted. Similarly current study also found significant results in relationship of organizational culture with organizational citizenship behavior in $\mathrm{H} 2(\mathrm{OC} \rightarrow \mathrm{OCB}),(\beta=0.763, \mathrm{sd}=0.025, \mathrm{t}=30.451, \mathrm{p}<=0.000)$ based on the findings $\mathrm{H} 2$ was also accepted in current study. The relationship between organizational citizenship behavior and knowledge sharing was also assessed and the current study found significant results in $\mathrm{H} 3(\mathrm{OCB} \rightarrow \mathrm{KS})(\beta=0.477$, sd $=$ $0.057, \mathrm{t}=8.327, \mathrm{p},<=0.000$ ) based on significant results $\mathrm{H} 3$ was also accepted. Besides the direct relationship assessment, the current study also found significant mediation of organizational citizenship behavior between organizational culture and knowledge sharing in $\mathrm{H} 4$ : $(\mathrm{OC} \rightarrow \mathrm{OCB} \rightarrow \mathrm{KS})(\beta=0.364, \mathrm{sd}=0.041, \mathrm{t}=$ $8.789, \mathrm{p}<=0.000$ ). Further details of the results are presented in in table 4 and figure 3.

Table 4. Assessment of Structural Model

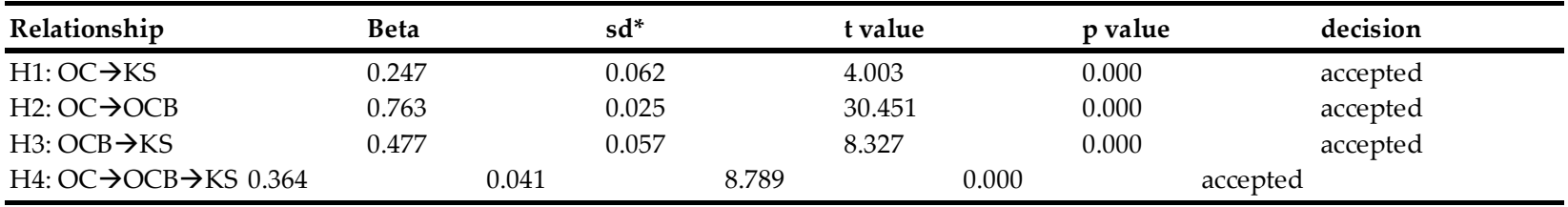

$\mathrm{Sd}^{*}=$ standard deviation.

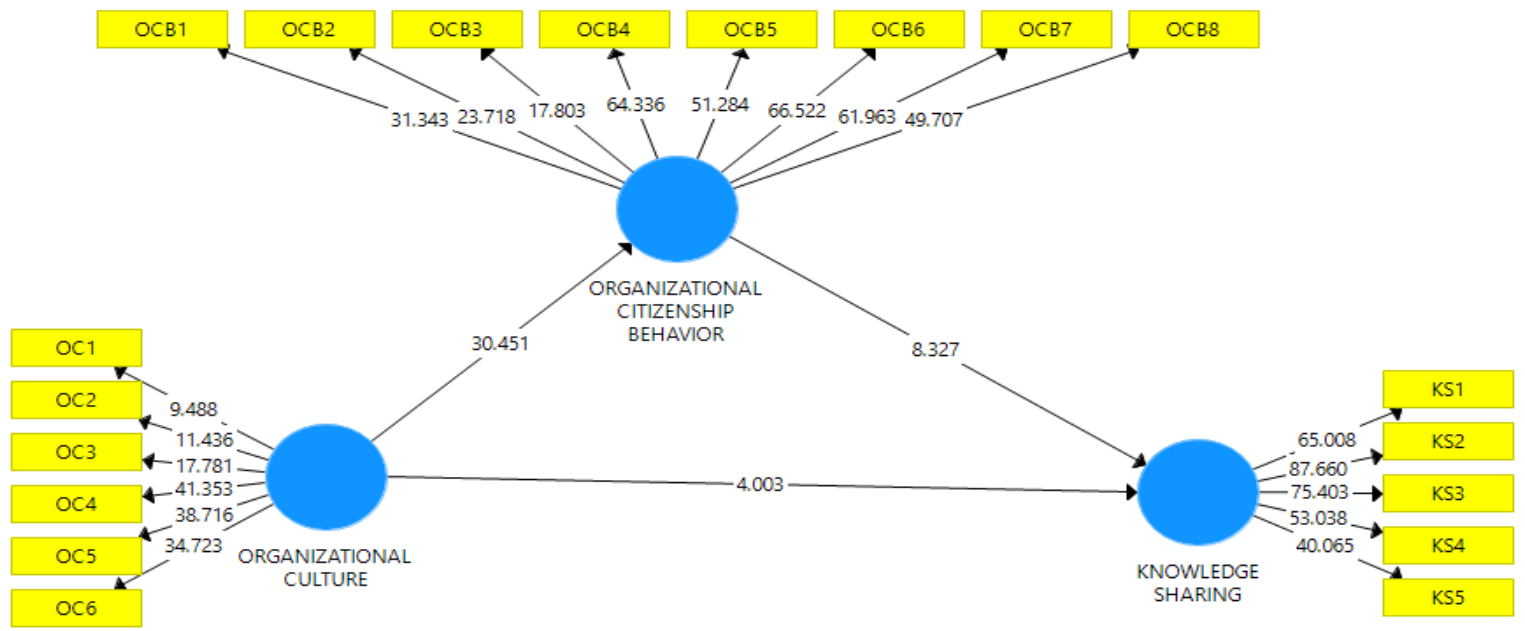

Figure 3. Structural Model 


\section{Discussion}

Findings of the current study show that organizational culture helps increase knowledge sharing significantly and has been in line with past literature (Asurakkody \& Hee: 2020; Abbasi \& Dastgeer: 2018; Aquilani et al., 2017). Positive organizational culture motivates the employees regarding knowledge sharing among groups, or knowledge sharing is good behavior for good social interaction at the workplace due to favorable organizational culture. This relationship between organizational culture and knowledge sharing can be stated by social exchange theory (Brown \& Pehrson, 2019). In different organizations, interaction or communication among employees is a valuable source for increasing knowledge sharing. Therefore, employees who easily share the knowledge within the workplace groups create a better environment, such as organizational culture.

Along with this, organizational citizenship behavior, which is known as voluntary actions of employees (Organ 1988), encourages employees towards knowledge sharing, as current study has proved with a significant effect of organizational citizenship behavior on knowledge sharing, which has also been in line with the past empirical evidence (Hsien et al., 2014; Pei-Lee \& Hongyi 2012; Hsu \& Lin 2008). Employees who are willing to share knowledge voluntarily show that they are motivated and do not have any hesitation while sharing knowledge because on one side, they are sharing knowledge, and on the other side, they are gaining knowledge from other group members at the workplace. Voluntary sharing of knowledge at the workplace also helps in skills to do other job tasks or support to substitute in case of emergency.

The current study also found a significant positive effect of organizational culture on organizational citizenship behavior. Moreover, the current study findings are supported by existing empirical research (Mahardika \& Wibawa 2019; Wijaya \& Yuniawan 2017; Cahyono et al., 2016). Thus positive culture creates willingness among employees, which motivates employees with voluntary behavior at work for better knowledge sharing. Such positive culture is direly crucial in the banking industry, though each bank department has different functions but on one another, all departments are linked with each other, as output of one department can be an input for other departments. Therefore, there should be such positive cultures in the banking industry that creates voluntariness among employees and encourage them to share knowledge at work.

Besides all direct relationships, the current study also found significant mediating effect of organizational citizenship behavior in the relationships of organizational culture with knowledge sharing. This recommends that employee willingness, like organizational citizenship behavior, engenders and encourages them to share knowledge at work between employees' organizational culture and knowledge sharing behavior. As a result, employees in the banking sector show volunteer behavior such as organizational citizenship behavior when they are provided with a positive culture, increasing their behavior for knowledge sharing. In a nutshell, organizational culture, organizational citizenship behavior of employees and knowledge sharing create a positive environment where employees feel a sense of organizational identification and become motivated and perform well and share knowledge among groups at work, which is ultimately beneficial for both organizations and employees.

\subsection{Theoretical Contribution}

Based on theoretical bases current study has contributed significant results in line with past literature that found significant positive effects of organizational culture on knowledge sharing (Asurakkody \& Hee, 2020; Abbasi \& Dastgeer: 2018; Aquilani et al., 2017), organizational culture towards organizational citizenship behavior (Mahardika \& Wibawa 2019; Wijaya \& Yuniawan 2017). Organizational citizenship behavior with knowledge sharing (Hsien et al., 2014; Pei-Lee \& Hongyi 2012). A current study found theoretical contribution under the umbrella of social exchange theory which states better relationship and exchange or sharing of knowledge among employees can be a better resource for both organizations and 
employees, especially bank employees. Furthermore, the mediating effect also contributed significant findings related to knowledge sharing. Therefore, the current study signified the research gaps by investigating relevant mediating variables that provide a more inclusive understanding of how organizational culture can be associated with knowledge sharing through organizational citizenship behavior as a mediating role.

\subsection{Practical Contribution}

Current research makes a valuable practical contribution by giving suggestions to management and organizations on creating a better organizational culture that helps to encourage employees for knowledge sharing. Therefore banks should focus on better organizational culture which attracts special assets in the shape of knowledgeable human capital. Precisely, creating a better organizational culture that improves or encourages employees' volunteer behavior onward affects knowledge sharing among employees. The findings of this study were supposed to be beneficial towards the management of the banking industry of the Kingdom of Bahrain, showing that organizational culture through organizational citizenship behavior engenders voluntariness among bank employees for knowledge sharing.

\subsection{Limitations and Recommendations for Future Research}

This research presents many limitations. Firstly, organizational culture, organizational citizenship behavior, and knowledge sharing were investigated via one-time collected data using a single method (questionnaire). This may raise the issue of common methods variance (Podsakoff, MacKenzie, Lee \& Podsakoff, 2003). To overcome this issue some different approaches were used, such as Harman test. Secondly, this study only investigated knowledge sharing through one independent variable and a single mediator. Future studies, therefore, may test other variables such as employee engagement which can encourage better employee knowledge sharing behavior, service climate, leadership styles, corporate social responsibility, and reward systems. Thirdly, the current study implied only mediations while moderators can also be added to better understand the examined relationships.

\section{Conclusion}

This research has made a valuable contribution regarding how banks may focus on organizational culture to encourage staff for knowledge-sharing behavior. Along with this, this empirical study has focused on the direct and as well as indirect effect of organizational citizenship behavior for better knowledge sharing. This research work has been based on strong empirical evidence that voluntarily behaving employees in the organization are helpful for the betterment of the organization and themselves.

\section{References}

Abbasi, S. G., \& Dastgeer, G. (2018). Organizational Culture and Knowledge Sharing Behavior: Examining Serial Mechanisms. Sukkur IBA Journal of Management and Business, 5(1), 33-51.

Ahmed, M., Arshad, A., Mahmood, A., \& Akhtar, S. (2019). The influence of spiritual values on employee's helping behavior: the moderating role of Islamic work ethic. Journal of Management, Spirituality \& Religion, 16(3), 1-29.

Ahmed, U. (2019). Influencing Youth Involvement in Entrepreneurship: Implications for Policy Makers in the Kingdom of Bahrain. Annals of Contemporary Developments in Management \& HR (ACDMHR), 1(3), 39-52.

Ahmed, U., Kura, K. M., Umrani, W. A., \& Pahi, M. H. (2020). Modelling the link between developmental human resource practices and work engagement: The moderation role of service climate. Global Business Review, 21(1), 3153.

Alavi, M.; \& Leidner, D.E. (2001) Knowledge management and knowledge management systems: Conceptual foundations and research issues. Mis Q. 25 107-136. 
AlZgool, M. R. H., Ahmed, U., Shah, S. A., AlMaamary, Q., \& AlMahmoud, N. (2020). Examining the interplay of hr initiatives, knowledge management, technological capabilities and product innovation. Journal of Security $\mathcal{E}$ Sustainability Issues, 10(2), 735-748.

AlZgool, M. R. H., Ahmed, U., Pahi, M. H., \& Ammar, A. (2020). COVID-19 and Work Engagement: Understanding the Nexus of Leaders Emotional Intelligence, Self-efficacy and Resilience in the Banking Sector of Bahrain. Revista Argentina de Clínica Psicológica, 29(3), 568-586.

Anderson, J. C., \& Gerbing, D. W. (1988). Structural equation modeling in practice: A review and recommended two step approach. Psychological bulletin, 103(3), 411-423.

Andrews, K. and Delahaye, B. (2000). Influence on knowledge processes in organizational learning: the psychosocial filter. Journal of Management Studies, 37(6), 797-810.

Aquilani, B., Abbate, T., \& Codini, A. (2017). Overcoming cultural barriers in open innovation processes through intermediaries: A theoretical framework. Knowledge Management Research E Practice, 15(3), 447-459.

Asurakkody, T. A., \& Kim, S. H. (2020). Effects of knowledge sharing behavior on innovative work behavior among nursing Students: Mediating role of Self-leadership. International Journal of Africa Nursing Sciences, 12, 100190.

Badawy, T. A. El, Trujillo-reyes, J. C., \& Magdy, M. M (2017). Exploring the Relationship between Organizational Culture, Organizational Citizenship Behavior and Job Satisfaction: A Comparative Study between Egypt and Mexico. International Journal of Management and Administrative Sciences (IJMAS), 4(06), 1-15.

Bambale, A. J. (2014). Relationship between servant leadership and organizational citizenship behaviors: Review of literature and future research directions. Journal of Marketing $\mathcal{E}$ Management, 5(1). https://www.questia.com/library/ Journal/1P3- 305228661/relationship-between-servant-leadership-andorganizational

Banks in Bahrain (2018). Banks in Bahrain. Retrieved from: http://www.banksbahrain.org/banking-in-bahrain/.

Bendak, S., Shikhli, A. M., \& Abdel-Razek, R. H. (2020). How changing organizational culture can enhance innovation: Development of the innovative culture enhancement framework. Cogent Business E Management, 7(1), 1712125.

Blankenship, S.S.; Ruona, W.E. (2009). Exploring knowledge sharing in social structures: Potential contributions to an overall knowledge management strategy. Adv. Dev. Hum. Resour. 11, 290-306.

Bloodgood, J. M. (2019). Knowledge acquisition and firm competitiveness: The role of complements and knowledge source. Journal of Knowledge Management, 23(1), 46-66

Bock G-W, Zmud RW, Kim Y-G, Lee J-N. (2005). Behavioral intention formation in knowledge sharing: Examining the roles of extrinsic motivators, social-psychological forces, and organizational climate. MIS quarterly, 29(1), 87-111

Brown, R., \& Pehrson, S. (2019). Group processes: Dynamics within and between groups. Hoboken, New Jersey: John Wiley \& Sons.

Cahyono, B. C., Sularso, R. A., \& Sumani, S. (2016). Pengaruh budaya organisasi, kepemimpinan dan stress kerja terhadap organizational citizenship behavior (OCB) dengan kepuasan kerja sebagai variabel intervening pada tenaga medis RSU Kaliwates Kabupaten Jember. RELASI: JURNAL EKONOMI, 12(1), 400-413.

Cameron, K. S., \& Quinn, R. E. (2006). Diagnosing and changing organizational culture: Based on the competing values framework. John Wiley \& Sons.

Cameron, K.S. \& Quinn,R.E. (1999). Diagnosing and Changing Organizational Culture Based on the Competing Values Framework. Addison-Wesley Publishing Company, Inc.

Chen, M.-H.; Wang, H.-Y.; Wang, M.-C. (2018) Knowledge sharing, social capital, and financial performance: The perspectives of innovation strategy in technological clusters. Knowl. Manag. Res. Pract.16, 89-104.

Chiang, C. and Hsieh, T. (2012). The impact of perceived organizational support and psychological empowerment on job performance: the mediating effects of organizational citizenship behavior. International Journal of Hospitality Management, 31(1). 180-190.

Chin, W. W. (1998). The partial least squares approach to structural equation modeling. Modern Methods for Business Research, 295(2), 295-336.

Chow WS, Chan LS. (2008). Social network, social trust and shared goals in organizational knowledge sharing. Information \& Management. 45(7):458-65.

Chun, J. S., Shin, Y., Choi, J. N., \& Kim, M. S. (2013). How does corporate ethics contribute to firm financial performance? The mediating role of collective organizational commitment and organizational citizenship behavior. Journal of Management, 39(4), 853-877.

Colquitt, J.A., Conlon, D.E., Wesson, M.J., Porter, C.O.L.H., Ng, K.Y. (2001). Justice at the millennium: A meta-analytic review of 25 years of organizational justice research. J. Appl. Psychol. 86, 425-445. 
Cummings, J.N. (2004) Work groups, structural diversity, and knowledge sharing in a global organization. Manag. Sci.50, 352-364.

Demirel, Y., Elhusadi, I., \& Alhasadi, A. (2018). The Relationship between Organizational Citizenship Behavior and Organizational Factors. International Journal of Business and Management Invention (IJBMI), 7(3), 27-39.

Ebrahimpour, H., Zahed, A., Khaleghkhah, A., \& Sepehri, M. B (2011). A survey relation between organizational culture and organizational citizenship behavior. Procedia - Social and Behavioral Sciences, 30, 1920-1925.

Eder, J., \& Trippl, M. (2019). Innovation in the periphery: Compensation and exploitation strategies. Growth and Change, 50(4), 1511-1531.

Eskiler, E., Ekici, S., Soyer, F., \& Sari, I. (2016). The relationship between organizational culture and innovative work behavior for sports services in tourism enterprises. Physical Culture and Sport. Studies and Research, 69(1), 53-64.

Fornell, C., \& Larcker, D. F. (1981). Structural equation models with unobservable variables and measurement error: Algebra and statistics. Journal of Marketing Research, 18(3), 382-388.

Fralinger, B., \& Olson, V. (2007). Organizational culture at the university level: A study using the OCAI instrument. Journal of College Teaching E Learning (TLC), 4(11), 85-98.

Galdeano, D., Ahmed, U., Fati, M., Rehan, R., \& Ahmed, A. (2019). Financial performance and corporate social responsibility in the banking sector of Bahrain: Can engagement moderate?. Management Science Letters, 9(10), 1529-1542.

Ghashghaeinia, A. R., \& Hafezi, S (2015). Relationship between organizational culture and organizational citizenship behavior among personnel of Islamic Azad University of Fars. J. Appl. Environ. Biol. Sci, 5(11), 131-138

Haag, M., Duan, Y., \& Mathews, B. (2010). The impact of culture on the application of the SECI model. In M. Haag, Y. Duan, \& B. Mathews (Eds.), Cultural implications of knowledge sharing, management, and transfer: Identifying competitive advantage 26-47. Hershey, PA: IGI Global.

Hadjimichael, D., \& Tsoukas, H. (2019). Toward a better understanding of tacit knowledge in organizations: Taking stock and moving forward. Academy of Management Annals, 13(2), 672-703

Hashim, K.F. and Tan, F.B. (2015). The mediating role of trust and commitment on members' continuous knowledge sharing intention: a commitment-trust theory perspective. International Journal of Information Management, 35(2), 145-151.

Henseler, J., Ringle, C. M., \& Sarstedt, M. (2015). A new criterion for assessing discriminant validity in variance-based structural equation modeling. Journal of the Academy of Marketing Science, 43(1), 115-135.

Hofstede, G., \& Hofstede, G. J. (2005). Cultures and organizations, software of the mind: Intercultural cooperation and its importance for survival. New York: McGraw-Hill.

Hsien, L.C., Pei, N.F., Yung, P.C. and Sheng, C.T. (2014). A study on the correlations between knowledge sharing behavior and organizational citizenship behavior in catering industry: the viewpoint of theory of planned behavior. The Anthropologist, 17(3), 873-881.

Hsu, C.L. and Lin, J.C.C. (2008). Acceptance of blog usage: the roles of technology acceptance, social influence and knowledge sharing motivation. Information and Management, 45(1) 65-74.

Huang, J. C., \& Wang, S. F. (2003, April). Team composition and learning: How knowledge conversion abilities facilitate team learning processes. In The 4th European Conference on Organizational Knowledge, Learning, and Capabilities (OKLC2003). Barcelona, Spain: IESE Business School, University of Navarra.

Ibrahim, Y. \& Arshad, I. (2017). Examining the impact of product involvement, subjective norm, and perceived behavioral control on investment intentions of individual investors in Pakistan. Investment Management and Financial Innovations, 14(4), 181-193.

Jo, S. and Joo, B. (2011). Knowledge sharing: the influences of learning organization culture, organizational commitment, and organizational citizenship behaviors. Journal of Leadership E Organizational Studies, 18(3), 353-364.

Khan, M. A., Ismail, F. B., Hussain, A., \& Alghazali, B. (2020). The interplay of leadership styles, innovative work behavior, organizational culture, and organizational citizenship behavior. SAGE Open, 10(1), 2158244019898264.

Khan, S. K., Memon, M. A., \& Ramayah, T. (2018). Leadership and innovative culture influence on organisational citizenship behaviour and affective commitment: The mediating role of interactional justice. International Journal of Business and Society, 19(3), 725-747. 
LaFayette, B., Curtis, W., Bedford, D., \& Iyer, S. (2019). Knowledge capital-The big picture. Knowledge Economies and Knowledge Work (Working Methods for Knowledge Management), 87-104. Retrieved from https://doi.org/10.1108/978-1-78973-775-220191005

Lim, B.T.; \& Loosemore, M. (2017). The effect of inter-organizational justice perceptions on organizational citizenship behaviors in construction projects. Int. J. Manag. 35, 95-106.

Lin, H. (2006). Impact of organizational support on organizational intention to facilitate knowledge sharing. Knowledge Management Research E Practice, 4(1), 26-35.

Mahardika, I Nyoman Bayu Putra., dan I Made Artha Wibawa. (2019). Pengaruh Budaya Organisasi, Kepuasan Kerja, Komitmen Organisasional Terhadap Karyawan. E-Jurnal Manajemen Unud, 8(1), 7340- 7370.

Mahardika, INBP, \& Wibawa, DIMA (2019). The Influence of Organizational Culture of Job Satisfaction and Organizational Commitment on Organizational Citizenship Behavior in Employees. E-Journal of Management, 8(1), 380-410.

Mahdi, O. R., Nassar, I. A., \& Almsafir, M. K. (2019). Knowledge management processes and sustainable competitive advantage: An empirical examination in private universities. Journal of Business Research, 94, 320-334.

Memon, S. B., Syed, S., \& Arain, G. A. (2017). Employee involvement and the knowledge creation process: An empirical study of Pakistani banks. Global Business and Organizational Excellence, 36(3), 53-63

Mogotsi, I.C., Boon, J.A., \& Fletcher, L. (2011). Modelling the relationships between knowledge sharing, organisational citizenship, job satisfaction and organisational commitment among school teachers in Botswana, African Journal of Library Archives and Information Science, 21(1), 41-58.

Mohant, J., \& Rath, B. P (2012). Can Organizational Culture be a Predictor of Organizational Citizenship Behaviors? International Journal of Innovation, Management and Technology, 3(1), 26-29.

Organ, D.W. (1988). OCB: The Good Soldier Syndrome; Lexington Books: Lexington, MA, USA.

Oxford. (2019). Bahrain`s Banking sector remains stable despite fluctuations in the regional market. Retrieved from: https://oxfordbusinessgroup.com/overview/demonstrating-resilience-sector-remains-stabledespite-fluctuationsregional-market.

Pahi, M. H., Ahmed, U., Sheikh, A. Z., Dakhan, S. A., Khuwaja, F. M., \& Ramayah, T. (2020). Leadership and Commitment to Service Quality in Pakistani Hospitals: The Contingent Role of Role Clarity. SAGE Open, 10(4), 114.

Patra, A., \& Aima, M. H (2018). The Effect of Organizational Culture and Job Satisfaction on Organizational Commitments and the Implementation on Organizational Citizenship Behavior in Employees of Pt. Bali Towerindo Sentra Tbk. International Journal of Scientific and Research Publications, 8(12), 320-328.

Pei-Lee, T. and Hongyi, S. (2012). Knowledge sharing, job attitudes and organisational citizenship behavior. Industrial Management and Data Systems, 112(1), 64- 82.

Podsakoff, N. P., Whiting, S. W., Podsakoff, P. M., \& Blume, B. D. (2009). Individual and organizational level consequences of organizational citizenship behaviors: A meta-analysis. Journal Applied Psychology, 94(1), 122-141.

Podsakoff, P. M., MacKenzie, S. B., Moorman, R. H., \& Fetter, R. (1990). Transformational leader behaviors and their effects on followers' trust in leader, satisfaction, and organizational citizenship behaviors. The leadership quarterly, 1(2), 107-142.

Podsakoff, P.M., MacKenzie, S., Lee, J. and Podsakoff, N. (2003). Common method biases in behavioral research: a critical review of the literature and recommended remedies. Journal of Applied Psychology, 88 (5). 879-903.

Purnama, C. (2013). Influence analysis of organizational culture organizational commitment job and satisfaction organizational citizenship behavior (OCB) toward improved organizational performance. International Journal of Business, Humanities and Technology, 3(5), 86-100.

Riggle, R.J.; Edmondson, D.R.; \& Hansen, J.D. (2009). A meta-analysis of the relationship between perceived organizational support and job outcomes: 20 years of research. J. Bus. 62, 1027-1030.

Sachdeva, G. (2019). Knowledge management systems leveraging the competitive advantage of top it organizations: A multi-case study of benchmarking practices. In S. Fong, S. Akashe, \& P. Mahalle (Eds.), Information and communication technology for competitive strategies 53-63. Singapore: Springer.

Setyaningrum, R. P. (2017). Relationship between servant leadership in organizational culture, organizational commitment, organizational citizenship behaviour and customer satisfaction. European Research Studies Journal, 20(3A), 554-569. 
Stamper, C. L., \& Dyne, V. L. (2001). Work status and organizational citizenship behavior: A field study of restaurant employees. Journal of Organizational Behavior, 22(5), 517-36.

Supriyanto, A. S., Ekowati, V. M., Haris, A., Soetjipto, B. E., Harianto, R., \& Yahya, M. (2020). The Effect of Organizational Citizenship Behavior on Job Satisfaction Mediated with Spiritual Leadership. International Journal of Business and Society, 21(2), 737-748.

Tamayo-Torres, J.; Roehrich, J.K.; Lewis, M.A. (2017) Ambidexterity, performance and environmental dynamism. Int. J. Oper. Amp; Prod. Manag. 37, 282-299.

Tamer Cavusgil, S.; Calantone, R.J.; Zhao, Y. (2003). Tacit knowledge transfer and firm innovation capability. J. Bus. Ind. Mark. 18, 6-21.

Tuan, L.T. (2017), Knowledge sharing in public organizations: the roles of servant leadership and organizational citizenship behavior. International Journal of Public Administration, 40(4). 361-373.

Villalobos Antúnez, JV, \& Ganga Contreras, F. (2018). Techno-business and Techno-discovery: A Perspective from Business Bioethics. Revista Fronteiras: Journal of Social, Technological and Environmental Science, 7 (3), 214-230.

Wang, R. (2019) Evolutionary game of knowledge sharing in master-apprentice pattern of innovative organization. Int. J. Innov. Sci. 11, 436-453.

Wijaya, N. A., \& Yuniawan, A. (2017). Analisis Pengaruh Budaya Organisasi dan Dukungan Organisasi Terhadap Organizational Citizenship Behavior dengan Komitmen Organisasi sebagai Variabel Intervening (Studi pada Karyawan Bagian Antaran PT. Pos Indonesia Processing Center Semarang). Diponegoro Journal of Management, 6(4), 666-678.

Yu, D.; Yang, J. (2018) Knowledge management research in the construction industry: A review. J. Knowl. Econ. 9, 782803.

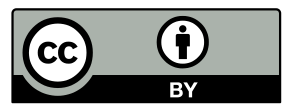

(C) 2021 by the author(s). Published by Annals of Contemporary Developments in Management \& HR (ACDMHR), under the terms and conditions of the Creative Commons Attribution (CC BY) license which can be accessed at http://creativecommons.org/licenses/by/4.0/. 